\title{
The Second Demographic Transition in the United States: Exception or Textbook Example?
}

\author{
RON J. LESTHAEGHE \\ LISA NEIDERT
}

THE NOTION THAT the demographic transition in the West has two distinct phases was originally suggested by Lesthaeghe and van de Kaa (1986) and elaborated by van de Kaa (1987). These authors proposed the terminology of a first and second demographic transition. The 1986 article posited that new living arrangements, and cohabitation (premarital or postmarital) in particular, were not solely the outcomes of changing socioeconomic conditions or rising female employment, but equally the expression of secular and anti-authoritarian sentiments of better-educated men and women who held an egalitarian world view, placed greater emphasis on Maslow's (1954) "higher order needs" (i.e., self-actualization, individualistic and expressive orientations, need for recognition), and, to use Inglehart's term (1970, 1990), had stronger "postmaterialist" political orientations. Furthermore, the second demographic transition would also be characterized by substantial postponement of both marriage and parenthood, and by an increase in the share of births to unmarried couples. If fertility control during the first transition was a matter of avoiding births of higher parities and births at older ages in order to safeguard the opportunities of the children already born, during the second it is a matter of postponing or eschewing parenthood altogether because of more pressing competing goals such as prolonging education, achieving more stable income positions, increased consumerism associated with self-expressive orientations, finding a suitable companion and realizing a more fulfilled partnership, keeping an open future, and the like (see also Ariès 1980). At the aggregate level postponement of fertility would not only lead to a temporary dip of fertility below replacement level, but to structural, long-term subreplacement cohort fertility. This in turn would create a growing need for "replacement migration." Thus the second demo- 
graphic transition will be directly linked to the further development of Western societies in a multiethnic and multicultural direction (van de Kaa 2002; Lesthaeghe and Surkyn 2006).

Twenty years after its introduction, the relevance of the term "second demographic transition" may still be contested, but the manifestation of what it predicted is not: by now, every characteristic of the second demographic transition has spread to the majority of industrialized Western populations, including Mediterranean and Central European countries. ${ }^{1}$ And, judging from the latest data on extraordinary degrees of postponement of marriage and fertility in the Far East (e.g., Jones 2006; Retherford and Ogawa 2005), and from very recent information on cohabitation in Japan (Raymo and Iwasawa 2006), non-Western industrialized or industrializing populations could also be following suit. If this proves to be the case, the second demographic transition will be more than what David Coleman (2003) called a "parochial northwestern European idiosyncracy."

But is the United States an exception to all of this? The US total fertility rate rose from 1.81 births per woman in 1981 to just above replacement level in 2001. The American total fertility rate now towers high above those of many of its industrial competitors, and especially above those of the EU25 and Japan. Add to this that the United States is still taking in more immigrants, and the conclusion is clear: the US population will continue to grow, its aging will be less pronounced, and the country will easily avoid the negative population growth momentum that many other industrialized countries are about to face as a result of 25 years of "lowest-low" fertilitythat is, TFRs below 1.5 children.

The social historian and conservative commentator Allan C. Carlson (2005) wrote the following about "American demographic exceptionalism":

Europe is dying; so may be Japan, also done in by a broad rejection of children. However, unlike the late 1960s and 1970s, when America was leading the global retreat from marriage and children, something different is now happening here: Americans are breaking free from the Malthusian darkness. (p. 8)

Carlson offered explanations:

This was not, as some suggest, a function of a rising number of births out of wedlock. Between 1995 and 2000, even marital fertility rose by 11 percent, the first sustained increase in that number since the mid-1950s. Nor was this a function of America's greater ethnic diversity. The increase in fertility among Americans of European descent actually climbed by 19 percent after 1981, to a total fertility rate of 2.065 .

The best explanation for America's greater fecundity is the higher degree of religious identification and behavior shown by Americans, when compared 
to Europeans. In the year 2000, 45 percent of Americans reported attending religious services during the prior week; in Europe, under ten percent. (ibid.)

The notion of American demographic "exceptionalism" and its international significance is echoed in influential publications (e.g., Eberstadt 2004; Torrey and Eberstadt 2005). Also, The Economist (2002) projected that by 2050 the US population will be half a billion and the EU-15 population will have declined to just over half its current size of 382 million. And Phillip Longman echoes these views in Foreign Affairs (2004) and in an editorial in USA Today (13 March 2006). As the editorial's title, "The liberal baby bust," indicates, the core issue is again differential fertility between the religious and the secular. But in this piece, Longman clearly recognizes the duality in this respect within the United States, and links it directly to what is often referred to as the contemporary American version of the late-nineteenthcentury German Kulturkampf, or "American Culture War" (cf. Hunter 1991). Longman writes:

Tomorrow's children, therefore, unlike members of the postwar baby boom generation, will be for the most part descendants of a comparatively narrow and culturally conservative segment of society. To be sure, some members of the rising generation may reject their parents' values, as often happens. But when they look for fellow secularists with whom to make common cause, they will find that most of their would-be travelers were quite literally never born.

Many will celebrate these developments. Others will view them as the death of the Enlightenment. Either way, they will find themselves living through another great cycle of history.

Is the US population immune to the transition features as a result of higher spiritual values and social conservatism? Or is its course a sub-narrative of the presumed "Culture War" between the "red" (Republican) and the "blue" (Democratic) parts of America, with the "red" outbreeding the "blue"? Or is it a more complex story in which ethnic differentials in fertility make an appreciable difference, and in which older, typical American features such as high teenage and poverty-related single motherhood still play a major role?

We first summarize the most important US trends in fertility and household formation patterns. But the lion's share of the analysis is devoted to the description of American spatial patterns of fertility and household formation among non-Hispanic whites and to the detection of their correlates. We perform this analysis first at the level of the 50 states and subsequently for the 3,141 counties. ${ }^{2}$ From this analysis it will be abundantly clear that the United States is a heterogeneous country, with even more variation within its borders than within the EU-25, and that many of its features come 
closer to being textbook examples of the second demographic transition than to "demographic exceptionalism." Finally, in what follows we refer often to ethnic distinctions in the United States since large parts of the Hispanic population are still in the process of completing their first demographic transition and therefore statistically distort the picture for most of the other segments of the population.

\section{Major components of the second demographic transition in the United States}

Marriage and fertility postponement, premarital cohabitation, and even fertility within cohabitation in the United States follow trends similar to those in western Europe, but spatial variation also remains very important in the United States.

Age at first marriage for both non-Hispanic white and black populations has been rising since the 1970s, in tandem with a rise in both single living and especially cohabitation. As can be seen in Table 1, the majority (62 percent) of the cohort of white women born in 1950-54, and reaching age 25 in the late 1970s, were married by age 25 without premarital cohabitation. In that cohort, a further 12 percent were already married by that age, but had started a cohabiting union before their marriage. Another 6 percent of white women were still in cohabitation by age 25 , and only 20 percent had not yet started a union. The contrast with the cohort born in the years 1965-69, and reaching age 25 in the early 1990s, is striking. For the latter the proportion directly moving into marriage was almost halved,

TABLE 1 Patterns of union formation among US white and black women: Status at age 25 for four birth cohorts

\begin{tabular}{lllll}
\hline & No union & $\begin{array}{l}\text { Cohabiting } \\
\text { and not } \\
\text { married }\end{array}$ & $\begin{array}{l}\text { Married } \\
\text { after } \\
\text { cohabitation }\end{array}$ & $\begin{array}{l}\text { Married } \\
\text { without } \\
\text { cohabitation }\end{array}$ \\
\hline $\begin{array}{l}\text { White women, cohort of } \\
\text { 1950-54 }\end{array}$ & 20 & 6 & 12 & 62 \\
$1955-59$ & 22 & 11 & 18 & 49 \\
$1960-64$ & 25 & 14 & 21 & 40 \\
$1965-69$ & 29 & 14 & 25 & 32 \\
Black women, cohort of & & & & \\
$1950-54$ & 31 & 12 & 13 & 44 \\
$1955-59$ & 47 & 16 & 10 & 27 \\
$1960-64$ & 44 & 22 & 12 & 22 \\
$1965-69$ & 46 & 23 & 14 & 18 \\
\hline
\end{tabular}

SOURCE: US National Survey of Family Growth 1995 as reported by Raley 2000: Figure 2.5. 
from 62 percent to 32 percent, and the shares of those married after cohabitation and of those still in cohabitation by age 25 both doubled. Also, the proportion still single rose from 20 percent to 29 percent. Note the shift among the black population as well: by age 25 , the fraction directly married without prior cohabitation declined from 44 percent to 18 percent in the same period, whereas the proportion still cohabiting by age 25 nearly doubled. Age at first marriage was rising, largely because of the spread of cohabitation. In other words, the United States in this respect exhibits a trend similar to Europe's since the 1970s.

However, as is also the case in the EU (from Sweden to Greece), the overall American pattern hides large spatial differentials. The degree of heterogeneity can be seen in Figure 1, where the 50 states are plotted according to an indicator of marriage postponement and an indicator of the incidence of cohabitation. ${ }^{3}$ Marriage postponement is measured by the proportion of women aged 25-29 never married as recorded in the US Census of 2000, and cohabitation as the percentage of all households headed

FIGURE 1 Location of 50 US states according to the postponement of marriage (y-axis) and the incidence of cohabitation (x-axis), 2000

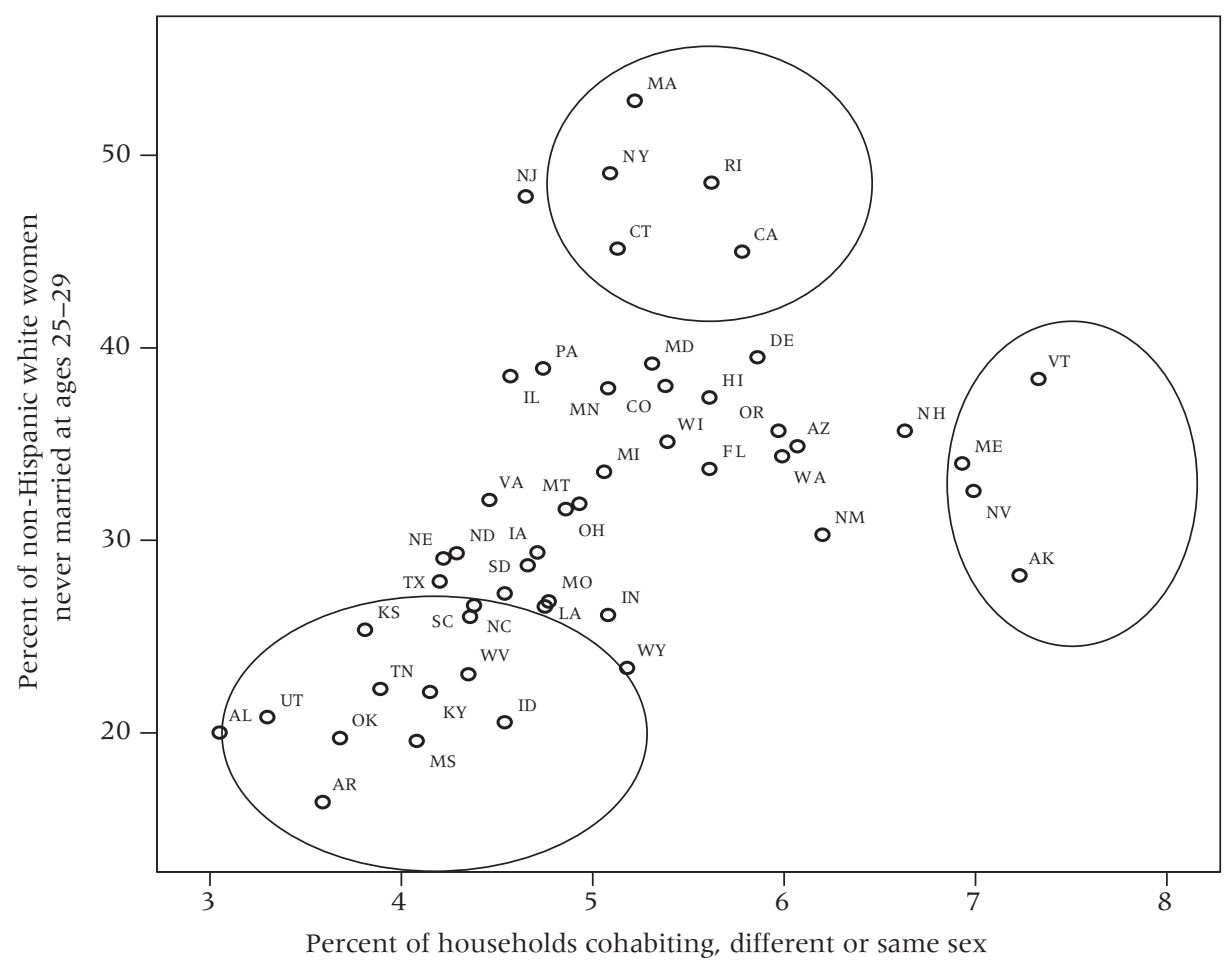

SOURCE: US Census Bureau 2003b. 
by unrelated adults of the same or a different sex. The positive relationship between the two indicators is apparent $(\mathrm{r}=.51)$, but the main purpose of the figure is to highlight the position of the various states in this two-dimensional space of marriage being postponed or declining in favor of cohabitation. The plot and circles reveal several clusters with distinct patterns.

1) Early marriage and little cohabitation. A large part of the South fits this picture, with states ranging from West Virginia, Tennessee, Kentucky, and the Carolinas to Alabama, Mississippi, Oklahoma, Arkansas, and Texas. But also Utah and Idaho in the West have less than a quarter of non-Hispanic white women never married in the age group considered, in combination with less than 5 percent of households headed by cohabiters.

2) Very late first marriage and moderate levels of cohabitation. In this group are several Northeastern states-New York, Massachusetts, Rhode Island, New Jersey, Connecticut-as well as California.

3) High levels of cohabitation with moderate proportions of never-married women 25-29. This group contains the rest of New England, but also Nevada and Alaska. Evidently, the states in group 3 have a higher proportion of younger adults in a union (either marriage or cohabitation) than states in group 2.

A similar picture emerges in Figure 2 with respect to same-sex households. The incidence of cohabitation is expressed as a percentage of all households, whereas that of same-sex cohabitation is pro mille. Same-sex cohabitation is still an exceptional feature and taking it as the cause of low fertility, as some conservative commentators suggest (e.g., Gallagher 2006), is not supported.

Figure 2 shows a correlation $(r=.60)$ between the incidence of samesex and overall cohabitation. As in the previous figure, quite a bit of variation remains. The striking feature of the plot is two clusters of states that are more differentiated by the incidence of same-sex households than by the incidence of overall cohabitation. Also, among the states that have higher percentages cohabiting (above 5 percent), some have considerably higher shares (above 7 per thousand) of same-sex households than others. The most "tolerant" states with respect to both cohabitation and same-sex cohabitation are Vermont and California, followed by Massachusetts, Washington, New York, Delaware, Florida, and Maine. These states are closely followed by a few others such as Colorado, Oregon, New Mexico, and Hawaii. At the other extreme are states with low incidences of both same-sex and overall cohabitation, but there is no systematic Southern cluster. Instead, the low cohabitation states on both accounts are often Midwestern and include the Dakotas, Iowa, Kansas, Nebraska, Montana, and Idaho, along with Ohio, West Virginia, Kentucky, Oklahoma, and Arkansas.

In Europe and Canada the steady expansion of the proportions cohabiting was soon followed by the emergence of a new feature: parenthood within cohabitation without converting the union into a marriage. In countries with 
FIGURE 2 Location of 50 US states according to the incidence of same-sex cohabitation (y-axis) and all forms of cohabitation (x-axis), 2000

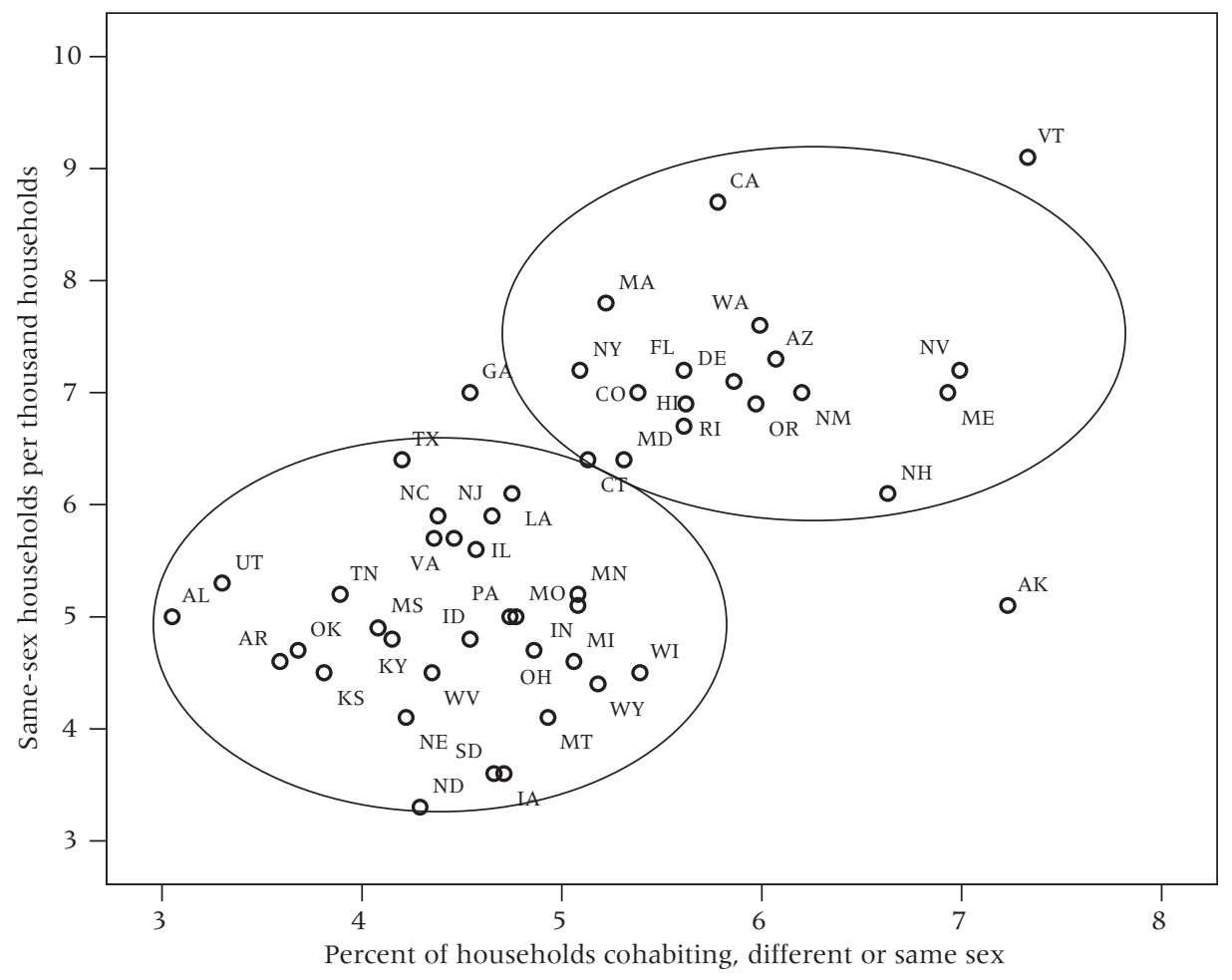

SOURCE: US Census Bureau 2003b.

low teenage nonmarital fertility, the trend of fertility within cohabitation can be documented by the increase in out-of-wedlock childbearing, but in the United States the matter does not permit such a straightforward interpretation. The main reason is that the birth rate among the unmarried has a number of contributing components that cannot easily be separated via the current background information. We would ideally like to know whether the birth occurred to a single mother or a cohabiting one, but there is no information in the vital registration on the presence of a partner in the household. Hence, to discover a trend in cohabitation fertility, we have to use indirect indications such as the age and ethnic affiliation of the mother.

Nonmarital fertility rose uninterruptedly from a low level of about 90,000 in 1940 to 1.47 million in 2003 (Medical News Today, 31 October 2005). As a share of all births, nonmarital births accounted for 3.8 percent in 1940 and 35.7 percent in 2003. The birth rate per thousand unmarried women aged 15-44 rose from 7 in 1940 to 46 in 2004 (NCHS 2005). But because the number of unmarried women has itself been grow- 
ing rapidly, the nonmarital birth rate has stabilized since the early 1990 s. In absolute numbers, nonmarital birth rates per five-year age group have declined steadily since 1991 among teenagers, but less so among older women, including those in their 30s (Ventura and Bachrach 2000: 24, NCHS 2005: Figure 1). In fact, women in the age groups 20-24 and 25-29 are the main contributors to the overall rise in numbers of nonmarital births after 1994. Moreover, the decline in the share of teenagers occurs among both blacks and whites, but the rise after age 20 is predominantly a white contribution (Ventura and Bachrach 2000: 19-20). These statistics fuel the speculation that there has been a gradual shift in relative contributions from teenagers remaining single to women in their 20s reproducing within cohabitation. This is corroborated by survey data (National Survey of Families and Households 1988; National Survey of Family Growth 1995-see Raley 2001: Table 4), which show that the share of all births contributed by cohabiting women aged 15-29 rose from about 5 percent in 1970-74 to 12 percent in 1990-94, and that of single women 15-29 rose from 13 percent to 23 percent. As a result, the share of births among married women declined from 82 percent to 65 percent over the same two decades. Also an increasing proportion of singles decided to cohabit before the child's birth, and a decreasing proportion of cohabitors converted their union into marriage before that birth (Seltzer 2000; Raley 2001). These survey figures document the trend prior to 1995, and no such clear decomposition is available for subsequent years. All available indications point toward both a greater incidence and a greater acceptability of procreation within cohabitation in the United States.

An additional, and major component of the second demographic transition is the postponement of parenthood and the development of a late fertility schedule. The degree of postponement can be documented by the proportions of women never married in the age group 25-29 or 30-34 and by the proportions who are still childless by these ages. In Figure 3 those percentages found in the 2000 census by state are shown for non-Hispanic white women aged 25-29.

There is, of course, a strong positive correlation between these postponement indicators $(r=.92)$, but the scatterplot mainly shows the spatial pattern of the unfolding of the second demographic transition. The vanguard in the United States with respect to postponement is once again made up of Massachusetts, New Jersey, New York, Connecticut, Rhode Island, and California. In these six states, about half of the non-Hispanic white women in this age group are not yet married, and more than 60 percent have not yet become parents. At the other extreme are states where less than a quarter of non-Hispanic white women are still single and less than 40 percent still childless. This group comprises West Virginia, Kentucky, Oklahoma, Mississippi, Arkansas, Utah, and Wyoming. 
FIGURE 3 Location of 50 US states according to percent never married (x-axis) and percent childless (y-axis) among non-Hispanic white women aged 25-29 in 2000

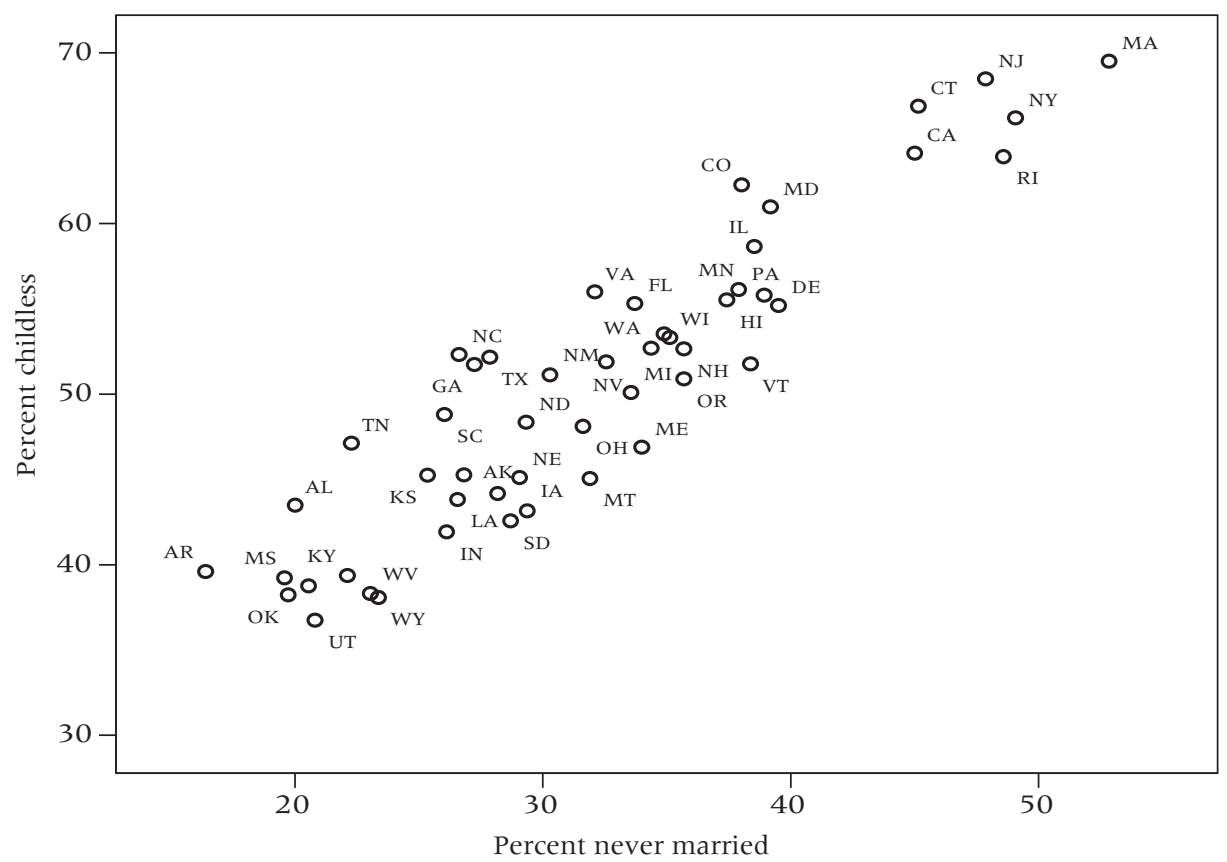

SOURCES: US Census Bureau 2003a and 2003b.

The postponement of fertility is also associated with fertility well below replacement, as shown in Figure 4, which plots the non-Hispanic white total fertility rate for 2002 against an index of fertility postponement for these women at the same date (data in Sutton and Mathews 2004). The index is the ratio of the sum of age-specific fertility rates above age 30 to the sum of these rates between ages 20 and 29.

The figure reveals that for the US non-Hispanic white population, only four states have above-replacement fertility (i.e., higher than 2.05 children): Utah, Idaho, Alaska, and Kansas. Three others come very close: Oklahoma, South Dakota, and Nebraska. All of these states have early fertility schedules for non-Hispanic white women. But in many other states, an early fertility schedule (not counting teenage fertility) is no guarantee against subreplacement fertility. For instance, Arkansas, Kentucky, West Virginia, Mississippi, and Wyoming have the youngest fertility schedules in the United States, but all have subreplacement fertility among non-Hispanic white women.

At the other end of the distribution the leading states with respect to postponement typically dip below a total fertility rate of 1.8 (California, New York, Connecticut) and even below 1.6 (Rhode Island and Massachusetts). 
FIGURE 4 Location of 50 US states according to the total fertility rate (TFR) ( $y$-axis) and the index of fertility postponement (x-axis) among non-Hispanic white women, 2002

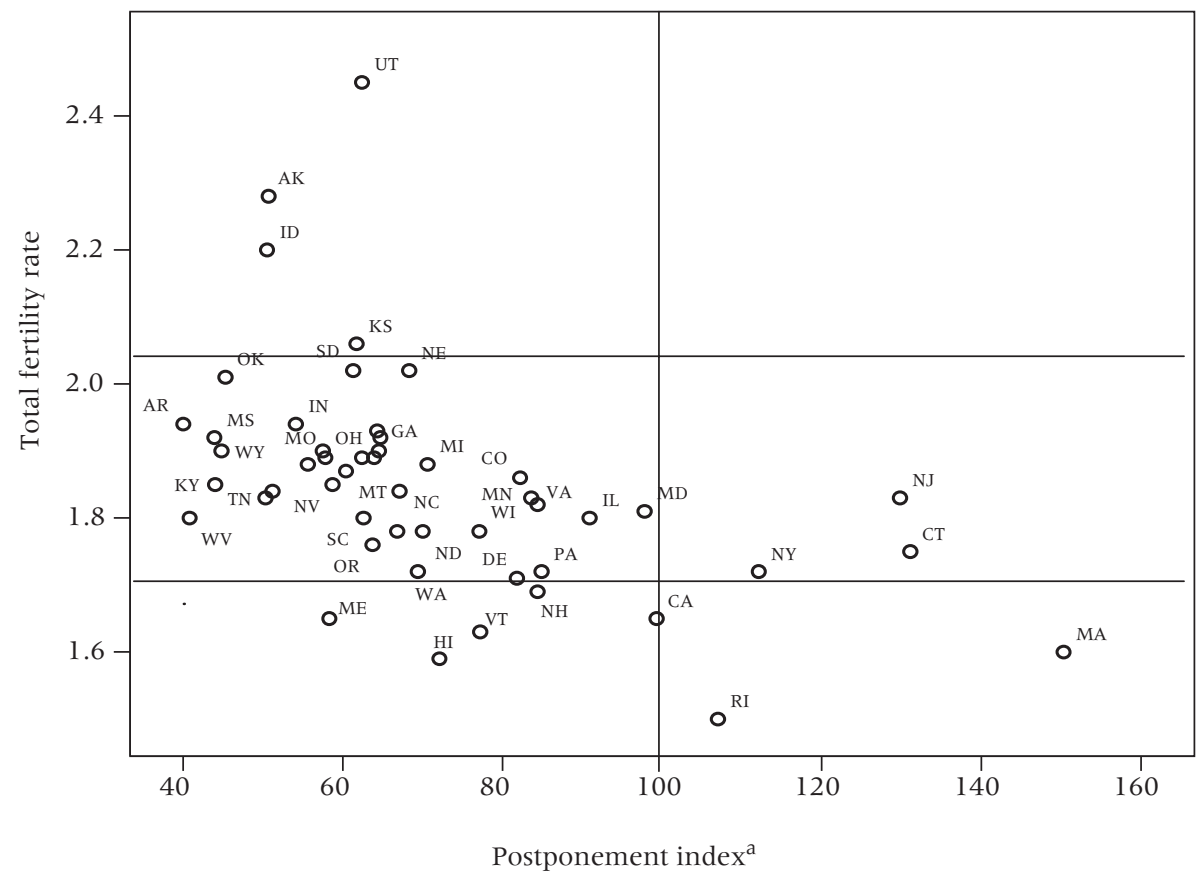

${ }^{a}$ Ratio of sum of age-specific fertility rates above age 30 to the sum of these rates between ages 20 and 29.

SOURCE: Sutton and Mathews 2004.

These states have fertility patterns that are highly similar to those of western European countries. In fact, in the European Union the Netherlands has long held the record in fertility postponement, with a peak in childbearing in the age group 30-34. As shown in Figure 5 non-Hispanic whites in Connecticut and New Jersey are just as late, and whites in Massachusetts bear children even later than the Dutch. For comparison the schedules for France and non-Hispanic whites in the United States as a whole are also included in the figure, together with the earliest age schedule of all US states, that of Arkansas.

If we take a typical western European or Scandinavian postponement index of about 0.80 as a benchmark and compare the US non-Hispanic white population with European populations, then we should add a number of other states to the American trio of Massachusetts (postponement index = 150 as against 126 for the Netherlands or 107 for Sweden), Connecticut (131) and New Jersey (130). These extra states would be: New York (112), Rhode Island (107), California (99), Maryland (98), Illinois (91) Minnesota 
FIGURE 5 Age-specific fertility rates (5-year age groups) in the Netherlands and France and among non-Hispanic whites in selected US states and the United States as a whole, 2002

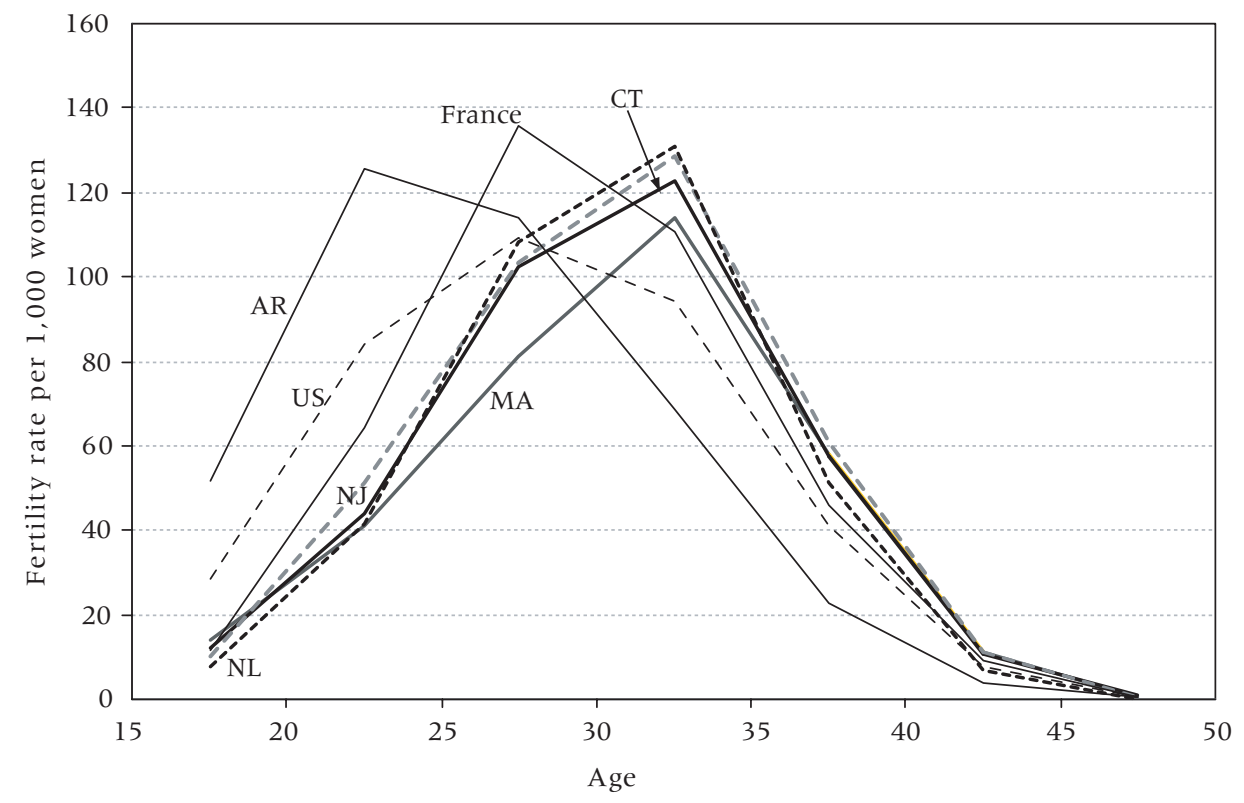

SOURCES: Council of Europe 2005, CD-ROM; Sutton and Mathews 2004

(84), New Hampshire (84), and Delaware (81). In these instances fertility after age 30 would be 80 percent or more of that between ages 20 and 29 . At the other end of the distribution the lowest postponement indexes in the non-Hispanic white populations of the United States are for Arkansas (40), Mississippi (41), West Virginia (41), Kentucky (45), Wyoming (45), Oklahoma (45), Tennessee (50), Alaska (51), Idaho (51), and Alabama (51).

From this analysis it is evident that the demographic map of the United States with respect to patterns of family formation exhibits strong contrasts. A sizable portion of the US non-Hispanic white population displays all the typical characteristics of the second demographic transition, whereas another major segment shows few signs of this new demographic pattern.

\section{Spatial patterns of family formation: Factors and correlates at the state level}

In this section we undertake a more detailed analysis of the spatial patterns of family formation in the United States and their socioeconomic, cultural, and political correlates. We enlarge the set of demographic indicators to include other variables pertaining to teenage and nonmarital fertility, inci- 
dence of abortion, divorce rates, and household composition measured at the level of the 50 states. We have chosen to use two indicators to capture a particular phenomenon in order to minimize idiosyncratic indicator effects. For instance, the incidence of abortion is measured once per thousand live births and once per thousand women aged 15-44. Similarly, fertility postponement is indicated by the postponement ratio (previously described) based on vital statistics and by the census-based percentages of women still childless at ages 25-29. In the current analysis, 19 demographic indicators are used, and they track two distinct dimensions in the patterning of American family formation. These two dimensions emerged clearly from a classic Principal Component Analysis (PCA), followed by a Varimax orthogonal factor rotation. Together the two factors explain 67.3 percent of the total

TABLE 2 Correlations between 19 demographic variables and their two underlying dimensions (factors): 50 US states

\begin{tabular}{|c|c|c|}
\hline & \multirow{2}{*}{$\begin{array}{l}\text { Factor } 1 \\
\text { Second } \\
\text { demographic } \\
\text { transition }\end{array}$} & \multirow{2}{*}{$\begin{array}{l}\text { Factor } 2 \\
\text { Vulnerable } \\
\text { women and } \\
\text { children }\end{array}$} \\
\hline & & \\
\hline $\begin{array}{l}\text { Percent non-Hispanic white women 25-29 } \\
\text { without children in household, } 2000\end{array}$ & .933 & -.186 \\
\hline $\begin{array}{l}\text { Percent non-Hispanic white women 25-29 } \\
\text { never married, } 2000\end{array}$ & .905 & -.370 \\
\hline $\begin{array}{l}\text { Percent non-Hispanic white ever-married women } \\
25-29 \text { without own children in household, } 2000\end{array}$ & .902 & -.097 \\
\hline Abortions per 1,000 live births, 1992 & .887 & .057 \\
\hline $\begin{array}{l}\text { Percent non-Hispanic white women 30-34 } \\
\text { never married, } 2000\end{array}$ & .882 & -.326 \\
\hline Abortion rate per 1,000 women 15-44, 1996 & .836 & .136 \\
\hline $\begin{array}{l}\text { Non-Hispanic white fertility postponement ratio } \\
\text { (fert. 30+/ fert. 20-29), } 2002\end{array}$ & .794 & -.411 \\
\hline Same-sex households per 1,000 households, 2000 & .754 & .191 \\
\hline Non-Hispanic white total fertility rate, 2002 & -.725 & .009 \\
\hline Non-Hispanic white fertility rate 15-19, 2002 & -.675 & .633 \\
\hline Percent households that are “families," 1990 & -.642 & .328 \\
\hline $\begin{array}{l}\text { Percent households with cohabiters of same or } \\
\text { different sex, } 2000\end{array}$ & .517 & -.148 \\
\hline Divorce rate per 1,000 population, 1990 & -.457 & .548 \\
\hline Total fertility rate, all races, 2002 & .338 & -.155 \\
\hline Percent nonmarital births, 1990 & .329 & .803 \\
\hline Percent births to teenagers, 1986 & -.303 & .875 \\
\hline Divorce rate per 1,000 population, 1962 & -.277 & .462 \\
\hline $\begin{array}{l}\text { Percent population } 30+\text { living with and responsible } \\
\text { for grandchildren, } 2000\end{array}$ & -.189 & .886 \\
\hline Percent nonmarital births, 2000 & .182 & .851 \\
\hline
\end{tabular}

NOTE: Correlations > .50 in bold. 
variance contained in the 19 indicators. The definitions of the variables and their respective correlations with the two underlying dimensions (i.e., factor loadings) are presented in Table 2 . The variables are ordered according to their strength of correlation with factor 1 .

The first principal component— the "second demographic transition" (or SDT) - is identified by the postponement indicators of both marriage and parenthood among non-Hispanic whites, the higher incidence of abortion, the nonconventional household types based on cohabitation, and low overall fertility levels. In other words, the first principal component clearly identifies the emergence of the second demographic transition in the 50 states.

As distinct from the western European pattern, however, divorce rates in the United States are not positively correlated with the SDT factor. The very early rises in American divorce rates from the late 1940s onward created a spatial pattern unrelated to that of the current second demographic transition. Catholic states maintained low divorce rates in the United States, while Protestant states had rising rates. The lesson here is that the early divorce maps do not predict the later SDT maps in the United States, whereas they do so in several EU countries (Lesthaeghe and Neels 2002).

The other principal component in Table 2 (uncorrelated with the first one)—for which we use the shorthand "vulnerable women and children"is identified by high teenage fertility, including that of non-Hispanic whites, high fertility out of wedlock, and the emergence of households in which grandparents have become the caretakers of children. This is evidently an older feature of early family formation in the United States, with unmarried teenagers or young women-black, white, or Hispanic-becoming mothers, ending up as single-parent households, or needing their own parents to look after their children.

The location of US states with respect to these two principal components of American family formation is shown in Figure 6. The four quadrants identify four contrasting types of family formation. At the bottom left are states that are resisting the SDT characteristics but that are also conservative in that they have few teenage mothers, low nonmarital fertility, and hence few grandparents needing to look after grandchildren. The states in this cluster are the Dakotas, Nebraska, Kansas, Iowa, Wyoming, Idaho, and Utah. The other cluster that is resistant to the second demographic transition so far, but has high proportions of teenage mothers, single mothers, and reliance on grandparents, is located in the lower right corner of the figure. It contains Southern states, such as South Carolina, Alabama, Mississippi, Louisiana, Tennessee, Oklahoma, and Arkansas.

The states in vanguard of the second demographic transition are found in the upper half of Figure 6, but they too are differentiated according to what happens with their children. High on measures of the second demographic transition, but with low teenage motherhood are several North- 
eastern states: Massachusetts, Vermont, Rhode Island, Connecticut, and New Jersey. Also advanced on second demographic transition measures but experiencing more early teenage fertility and single and needy parents are California and Nevada, but also Delaware and Florida. Aside from the four "corner" states in Figure 6 lies middle-of-the-road America with average scores on both factors. Examples are Michigan, Ohio, Virginia, and Oregon, all located near the center of the figure.

These two basic factors in US family formation can be related to a series of variables: economic (income, poverty), socioeconomic (education,

FIGURE 6 Location of states according to two principal components of US family formation (scales in standard deviations)

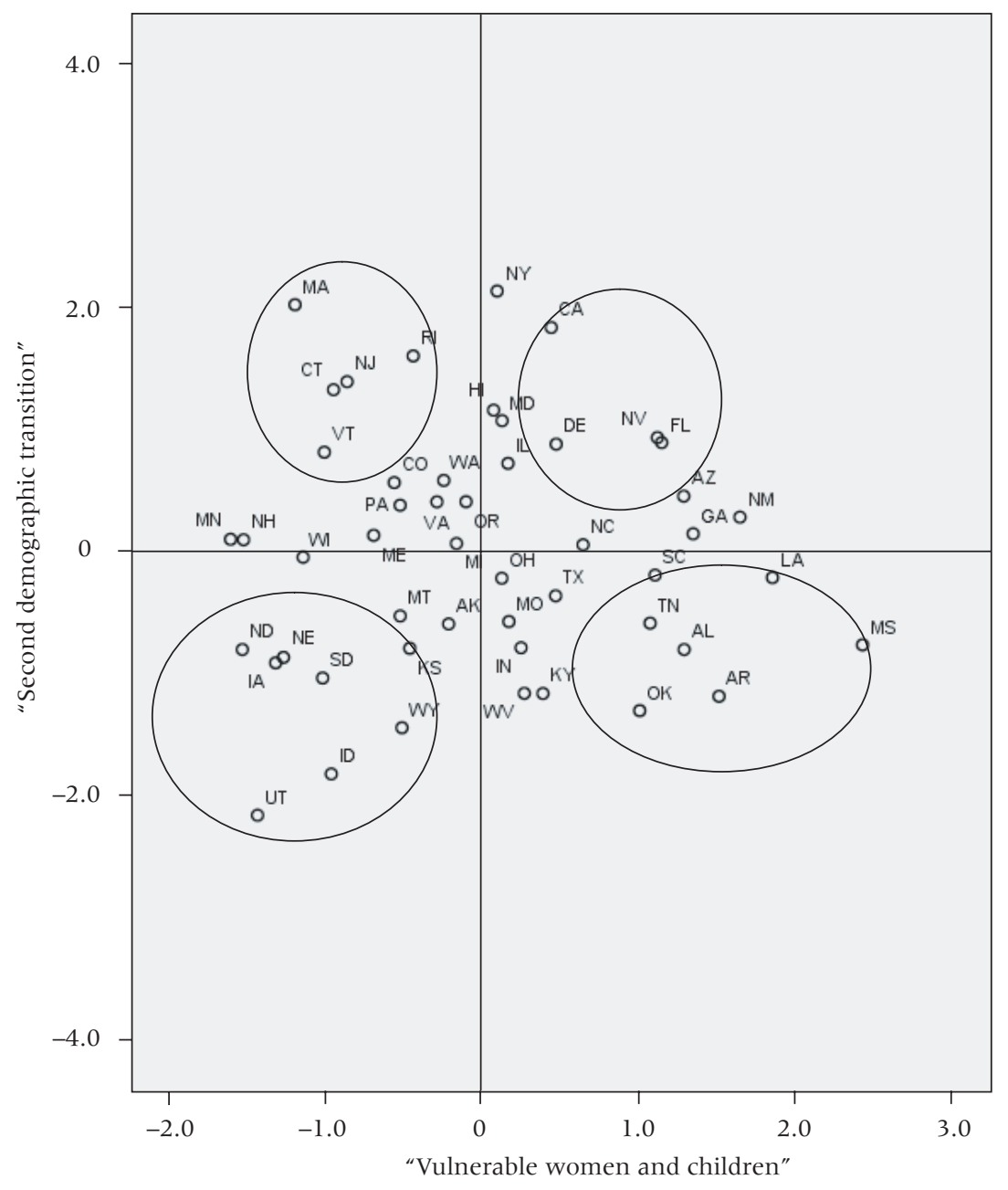

NOTE: For explanation of components see Table 2 and discussion in the text. 
TABLE 3 Selected political, socioeconomic, and cultural correlates of the two dimensions of US family formation, 50 US states

\begin{tabular}{ll}
\hline $\begin{array}{l}\text { A. Best correlates of the “second demographic } \\
\text { transition" dimension }\end{array}$ & -.88 \\
Percent vote for Bush, 2000 & -.87 \\
Percent vote for Bush, 2004 & +.70 \\
Disposable personal income, 2001 & +.68 \\
Percent metropolitan, 2000 & +.65 \\
Percent metropolitan, 1970 & +.62 \\
Percent Catholic, 1990 & -.62 \\
Percent Evangelical, 2000 & +.62 \\
Percent population 25+ with BA, 1990 & +.50 \\
Percent workers unionized, 2001 & +.49 \\
Disposable personal income, 1980 & -.46 \\
Percent vote Nixon 1972 (vs. McGovern) & -.43 \\
Percent vote Goldwater 1964 (vs. Johnson) & \\
B. Best correlates of the “vulnerable women & \\
$\quad$ and children" dimension & -.69 \\
Percent population 25+ HS graduates, 1990 & +.66 \\
Percent population in poverty 1998-2000 & +.66 \\
Percent population black, 2000 & -.61 \\
Percent population non-Hispanic white, 2000 & +.57 \\
Percent Evangelical/Mormon & +.54 \\
Percent vote Goldwater 1964 (vs. Johnson) & +.54 \\
Percent vote Nixon 1972 (vs. McGovern) & -.45 \\
Percent population 25+ with BA, 1990 & -.43 \\
Disposable personal income, 2001 &
\end{tabular}

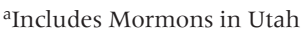

urbanization), political (voting), and cultural (ethnicity, religion). The results are presented in Table 3. Set A lists the various correlates of the "second demographic transition" dimension, and set B the best correlates of the "vulnerable women and children" component. These outcomes permit a further interpretation of the regional demographic picture of the United States.

Table 3 shows that the second demographic transition factor is strongly correlated with being a wealthier state, with disposable household incomes above the US average, and with being highly urbanized and high percentages of the population living in metropolitan areas. Moreover, the SDT map also correlates positively with high proportions of Catholic populations (many not practicing) and higher proportions of adults having college degrees (BA and higher). Finally, states with high proportions of unionized workers tend to score higher on the SDT factor.

The second demographic transition is clearly negatively correlated with high proportions being Evangelical Christians and with voting for conser- 
vative Republican candidates in past presidential elections, that is, in favor of Barry Goldwater (as opposed to Lyndon Johnson) in 1964 and in favor of Richard Nixon (against George McGovern) in 1972. But the most striking feature in Table 3 is the very strong negative correlation between the SDT pattern and the percentage vote for George W. Bush $(-.88$ and -.87$)$ in 2000 and 2004. The "blue states," which vote predominantly for Democratic candidates in local and national elections, are advanced on SDT measures, while the "red states," which vote predominantly for Republicans, lag. We return to this point later.

The correlates of the teenage and unmarried mothers indicators in Table 3 are well known: lower average disposable incomes, lower proportions finishing high school, higher proportions in poverty, higher proportions black or Hispanic, and high proportions of Evangelical Christians or Mormons. Many states within America's "Bible belt," which do not or only weakly exhibit the manifestations of the second demographic transition, tend to have more widespread poverty and low education, more common teenage childbearing, young single-mother families, and high divorce rates.

\section{The SDT-electoral voting connection}

On occasion demographers have been successful in helping to predict election results, although their preoccupation runs in the opposite direction: linking demographic outcomes to cultural and political indicators. Examples from Europe are the strong links between voting for secular parties and the speed of the fertility decline during the first demographic transition (e.g., Lesthaeghe and Wilson 1986), and the prediction of the regional outcomes in the Italian divorce referendum of the 1970s on the basis of the timing of the historical fertility transition 40 years earlier (Livi Bacci 1977). But the very strong negative correlation found in the United States between the SDT factor and the percentage of votes for George W. Bush in 2000 and 2004 is to our knowledge one of the highest spatial correlations between demographic and voting behavior on record.

While some may have expected these correlations to be stronger in 2004 than in 2000 because the electorate seems to have been far more divided and polarized on issues in 2004, an examination of selected results from the exit polls during both elections shows that most of the "cultural divide" was well established in 2000.

Table 4 shows the percentage of Americans voting for Bush in 2000 and 2004 according to their exit poll answers. The percentages according to demographic, moral, and cultural characteristics are remarkably similar in the two elections. For instance, 74 and 77 percent of those who felt abortion is always illegal voted for Bush in 2000 and 2004. The religious right voted overwhelmingly for Bush in both elections. 
TABLE 4 Percentage of Americans voting for George W. Bush in 2000 and 2004 according to responses to election day exit polls

\begin{tabular}{|c|c|c|}
\hline & 2000 & 2004 \\
\hline \multicolumn{3}{|l|}{ Demographic characteristics } \\
\hline Women & 43 & 48 \\
\hline White & 54 & 58 \\
\hline African American & 9 & 11 \\
\hline Hispanic & & 44 \\
\hline Married & 53 & 57 \\
\hline Married, with children & 56 & 59 \\
\hline Gay & 25 & 25 \\
\hline Union member & 34 & 38 \\
\hline \multicolumn{3}{|l|}{ Political identity } \\
\hline Democrat & 11 & 11 \\
\hline Liberal & 13 & 13 \\
\hline Conservative & 81 & 84 \\
\hline \multicolumn{3}{|l|}{ Religion/religiosity } \\
\hline Protestant & 56 & 59 \\
\hline White Protestant & 63 & 68 \\
\hline White religious right ${ }^{\mathrm{a}}$ & 80 & 78 \\
\hline Church, more than weekly & 63 & 64 \\
\hline Church, weekly & 57 & 58 \\
\hline Church, monthly & 46 & 50 \\
\hline Church, a few times a year & 42 & 45 \\
\hline Church, never & 32 & 36 \\
\hline \multicolumn{3}{|l|}{ Values } \\
\hline Abortion always legal & 25 & 25 \\
\hline Abortion mostly legal & 38 & 38 \\
\hline Abortion mostly illegal & 69 & 73 \\
\hline Abortion always illegal & 74 & 77 \\
\hline Clinton scandals were very important & 80 & - \\
\hline Lieberman's religion makes him a worse vice president & 72 & \\
\hline Moral values are most important issue & - & 80 \\
\hline Terrorism is most important issue & - & 86 \\
\hline Same-sex couples should be allowed to legally marry & - & 22 \\
\hline Things are going well in Iraq & - & 90 \\
\hline
\end{tabular}

${ }^{a}$ Choice was white religious right in 2000 and born-again white in 2004

SOURCE: «http://www.cnn.com/ELECTION/2004/pages/results/states/US/P/00/epolls.0.html» and «http:// www.cnn.com/ELECTION/2000/results/index.epolls.html».

Of course some issues, such as terrorism, the war in Iraq, and same-sex marriage, were irrelevant in 2000. Voters' views on these issues were strongly associated with their vote in 2004. Some comparable items available in 2000 and not in 2004 were questions about the importance of the Clinton scandals 
and Joseph Lieberman's religion. President Clinton's liaison with Monica Lewinsky was viewed very unfavorably by Bush voters; likewise, Lieberman's Jewish faith was a negative factor (or perhaps a question mark).

We reproduce the scatterplot between the second demographic transition values and the vote for Bush across the 50 states. Because the correlation between a state's vote for Bush in 2000 and 2004 is .97, Figure 7 shows results only for 2004 .

Strong correlations also hold with respect to the various components of the SDT factor. For instance, the percentage voting for Bush correlates strongly with the percentage of non-Hispanic white women never married at ages 25-29 (postponement of first marriages) $(\mathrm{r}=-.84)$, with the percentage of non-Hispanic white women aged 25-29 without children (fertility postponement) $(\mathrm{r}=-.78)$, and with the non-Hispanic white total fertility rate in $2002(\mathrm{r}=+.78)$. This last relationship is shown in Figure 8.

These findings beg the question whether the zero-order correlations are spurious. More specifically, it would be inappropriate to give the corre-

FIGURE 7 Relationship between the SDT factor and the vote for Bush in 2004, US 50 states $(r=-.87)$

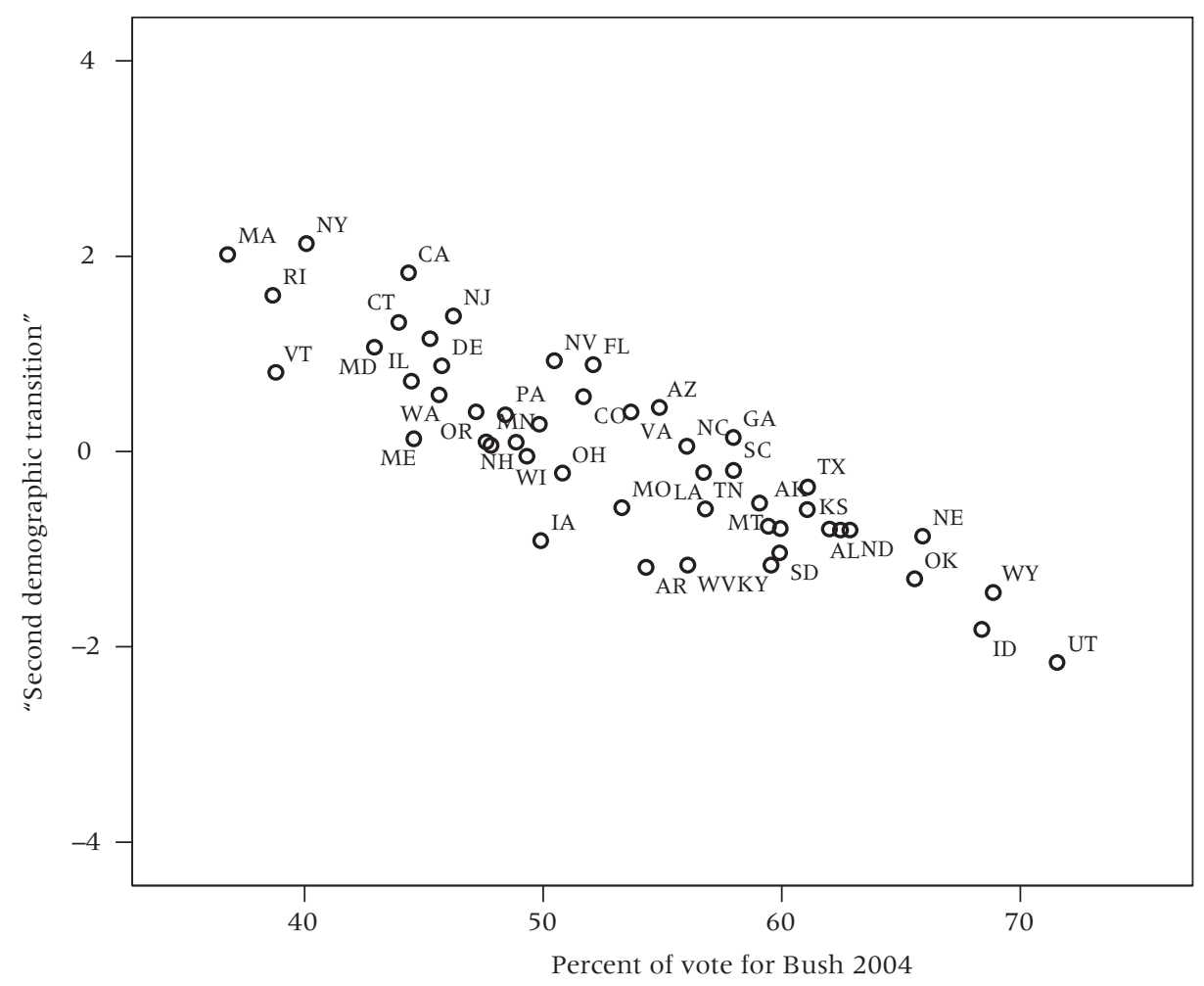


FIGURE 8 Relationship between the non-Hispanic white total fertility rate in 2002 and the percentage vote for Bush in 2004, US 50 states $(r=+.78)$

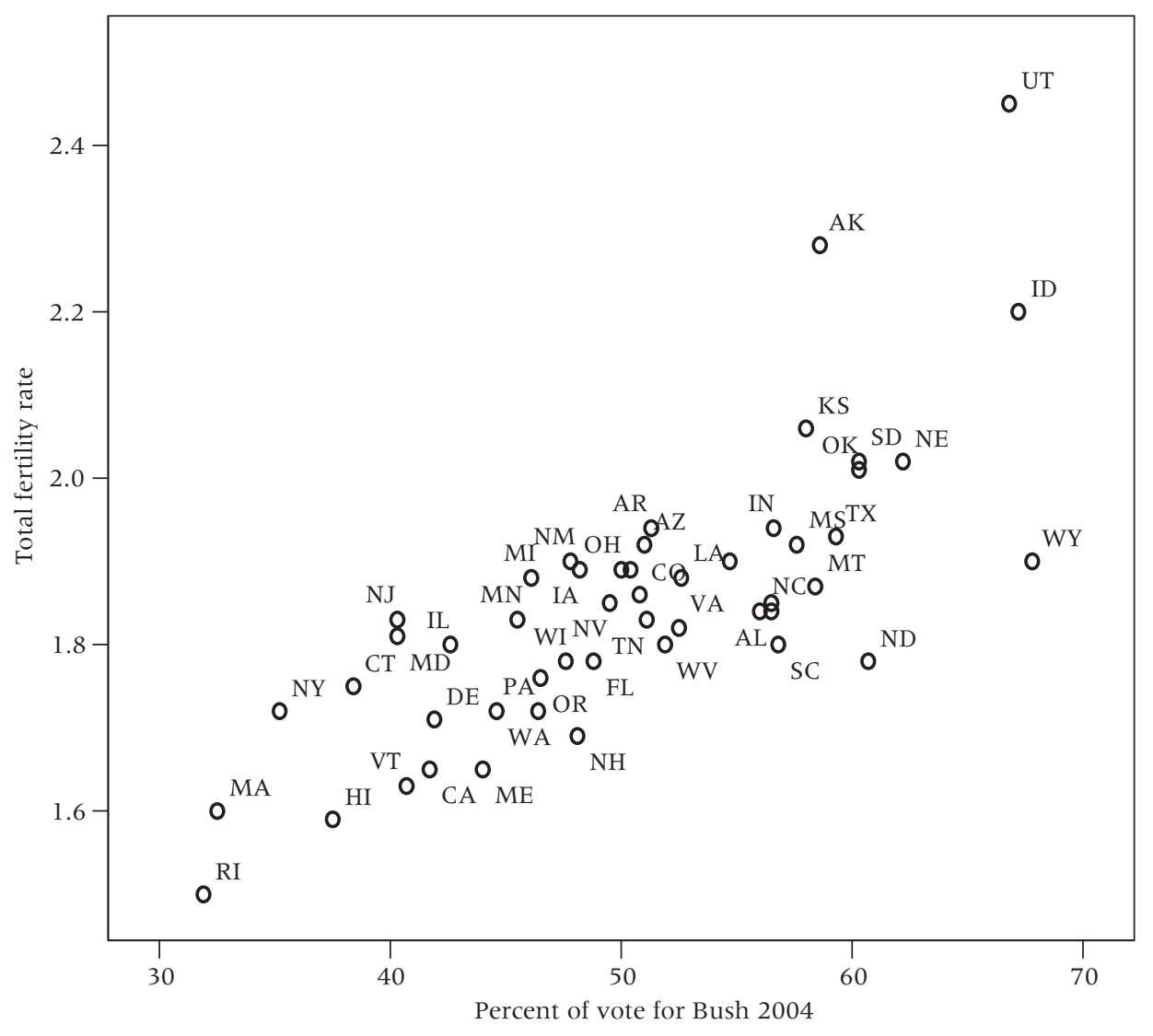

lations a direct causal interpretation, since they could be the result of a common set of other variables that causally influence both demographic behavior and voting pattern. In other words, two variables that are themselves causal results of the same determinants must of necessity be correlated.

To check this hypothesis, we performed a number of partial correlation tests. The zero-order correlation between voting and the SDT factor will be spurious if the partial correlations are zero or are drastically reduced. The outcomes of the test are reported in Table 5 for the correlation between voting for Bush and the non-Hispanic white total fertility rate and the second demographic transition factor as identified in Table 2.

The first partial correlation test assumes that the common causal factors producing a high zero-order correlation between the demographic and the voting variables are structural in nature, for example, related to a state's average disposable household income, educational level, and degree of urban- 
TABLE 5 Partial correlations: Are the zero-order correlations between the non-Hispanic white total fertility rate or the SDT factor and the vote for Bush in the 50 US states resistant to controls?

\begin{tabular}{|c|c|c|c|c|}
\hline & \multicolumn{2}{|c|}{$\begin{array}{l}\text { Non-Hispanic white } \\
\text { TFR } 2002 \text { and } \\
\text { vote for Bush in }\end{array}$} & \multicolumn{2}{|c|}{$\begin{array}{l}\text { SDT factor } \\
\text { and vote for } \\
\text { Bush in }\end{array}$} \\
\hline & 2000 & 2004 & 2000 & 2004 \\
\hline No controls & .771 & .782 & -.880 & -.871 \\
\hline \multicolumn{5}{|l|}{ After controls for } \\
\hline \multicolumn{5}{|l|}{ Three structural variables } \\
\hline \multicolumn{5}{|l|}{ Disposable personal income, 2001} \\
\hline \multicolumn{5}{|l|}{ Percent population 25+ with BA, 1990} \\
\hline Percent population metropolitan, 2000 & .755 & .761 & -.787 & -.812 \\
\hline \multicolumn{4}{|l|}{ Percent black, 2000} & \\
\hline Percent Hispanic, 2000 & .755 & .761 & -.840 & -.853 \\
\hline \multicolumn{5}{|l|}{ Three structural variables + religion } \\
\hline Percent Catholic & .686 & .686 & -.734 & -.742 \\
\hline \multicolumn{4}{|l|}{ Religion alone } & \\
\hline Percent Catholic & .654 & .667 & -.788 & -.755 \\
\hline
\end{tabular}

ization. When the three best correlates of these independent dimensions are controlled for, the partial correlation is barely reduced and still lies well above .70. Thus, the regional patterns related to income, education, and urbanization fail to account for the Bush-SDT and the Bush-TFR correlation.

The result is the same if we add two more variables related to the ethnic composition of a state. The percentage black and the percentage Hispanic in the total population in tandem with the three structural variables fail to reduce the partial correlation. The third panel shows the results of adding two variables related to religion to the structural ones. These are the percentage Evangelical or Mormon and the percentage Catholic. The reduction in the coefficient is somewhat larger, but the partial correlations are still in the neighborhood of .70, far from zero. In fact, if we omit the three structural variables and only make use of the two religion variables, the results are even more marked in reducing the Bush-white TFR partial correlation to around .65. For the Bush-SDT correlation, the largest reduction is achieved by retaining the three structural predictors and the religious variables $(-.73$ or -.74$)$.

The conclusion we draw is that the zero-order correlation between SDT variables and voting for Bush cannot be considered spurious or as the outcome of the operation of the common causal determinants used here. 
The control variables fail to reduce the zero-order correlation coefficients to an extent significant enough to warrant such a conclusion. And since the demographic picture was unfolding well before the 2000 and 2004 elections, we accept the hypothesis that the spatial pattern of the second demographic transition in the United States was a nonredundant co-determinant of the voting outcomes at the state level. But because states themselves are heterogeneous, we now examine the outcomes using counties as the unit of analysis before we formulate final conclusions.

\section{Do the findings hold at the county level?}

Correlation coefficients might turn out to be considerably weaker if we examine relationships among all 3,141 counties in the United States. Political scientists may only be interested in the relationship at the state level because only the state vote is important for presidential elections. However, our earlier findings will be far more robust if the relationships hold across counties and regions as well. To this end, we constructed a much larger data file, with multiple indicators for degree of urbanization, wealth and poverty, female education, ethnic composition, and religious affiliation. In addition, we constructed the demographic indicators for non-Hispanic whites wherever possible. Some measures are based on older data (1988), which allows us to capture the geographic pattern at earlier stages of the second demographic transition. ${ }^{4}$

As in the analysis of the 50 states, similar factors emerge as underlying demographic indicators for the 3,141 counties. As shown in Table 6 the SDT factor strongly correlates with the indicators of marriage and parenthood postponement and with the indicators of households formed on the basis of unmarried cohabitation. Negative correlates of the SDT factor are teenage fertility and the total fertility rate, which of course incorporates teenage fertility. On the other hand, an uncorrelated second factor loads strongly on teenage fertility, divorce, female-headed households, and children growing up with grandparents and in households other than that headed by a married couple. The second factor is again indicative of the degree of vulnerability of young women and children.

The SDT factor can be decomposed into (i) a "postponement" component, indicative of late marriage and, especially, late fertility and (ii) a "cohabitation" component. If the two separate components are constructed for the 3,141 counties, they correlate at the 0.69 level. In several European countries these two components of the second demographic transition-postponement and cohabitation-do not correlate as strongly, either over time or spatially. ${ }^{5}$ The stronger spatial correlation between these components in the United States makes the country more of a textbook example of the second demographic transition than an exception. 
TABLE 6 Demographic indicators and their two underlying factors: 3,141 US counties ${ }^{a}$

\begin{tabular}{|c|c|c|}
\hline & Factor 1 & Factor 2 \\
\hline & $\begin{array}{l}\text { Second } \\
\text { demographic } \\
\text { transition }\end{array}$ & $\begin{array}{l}\text { Vulnerable } \\
\text { women and } \\
\text { children }\end{array}$ \\
\hline Percent never-married women, 25-29 (WNH) & .837 & -.018 \\
\hline Percent age at first birth $=28+$ in $1988(\mathrm{WNH})$ & .812 & -.293 \\
\hline Mean age at first birth in 1988 (WNH) & .792 & -.410 \\
\hline Percent childless women, 25-29 (WNH) & .787 & -.091 \\
\hline Percent never-married women, 30-34 (WNH) & .780 & .074 \\
\hline $\begin{array}{l}\text { Fertility postponement ratio, } 1988 \\
\text { (fert. 30+/fert. 20-29) (WNH) }\end{array}$ & .733 & -.329 \\
\hline Percent cohabiting households (WNH) & .652 & .284 \\
\hline Percent cohabiting households (total) & .606 & .461 \\
\hline Percent teenage births, 1988 (WNH) & -.556 & .613 \\
\hline Percent same-sex cohabiting households (total) & .517 & .364 \\
\hline Total fertility rate, 1999 (WNH) & -.503 & -.143 \\
\hline Percent same-sex cohabiting households (WNH) & .495 & .263 \\
\hline $\begin{array}{l}\text { Percent population } 30+\text { living with and responsible for } \\
\text { grandchildren (WNH) }\end{array}$ & -.449 & .646 \\
\hline Percent population $30+$ living with grandchildren (WNH) & -.318 & .699 \\
\hline Percent children living in married-couple family (WNH) & -.273 & -.609 \\
\hline Percent children living in married-couple family (total) & -.245 & -.746 \\
\hline $\begin{array}{l}\text { Percent population 30+ living with and responsible for } \\
\text { grandchildren (total) }\end{array}$ & -.227 & .641 \\
\hline Percent unmarried births, 1988 (WNH) & .164 & .479 \\
\hline Percent currently divorced women, 35-44 (WNH) & .127 & .530 \\
\hline Percent population $30+$ living with grandchildren (total) & -.101 & .657 \\
\hline Percent female-headed families/households (total) & .069 & .706 \\
\hline Percent female-headed families/households (WNH) & .031 & .649 \\
\hline
\end{tabular}

NOTE: WNH= white non-Hispanic.

${ }^{\text {a Date is }} 2000$ unless otherwise specified. Correlations $>.50$ in bold.

The data for the 3,141 counties are also used to produce a set of colored maps of the various demographic dimensions discussed so far. As these cannot be reproduced here, we refer the reader to a website (www.sdt.psc.isr. umich.edu) containing these maps and annotations. Note that the counties maps exist in a classic version and in a demographically more meaningful version with counties drawn proportional to population size.

As in the state-level analysis, we examine the relationship between the second demographic transition factor and the vote for Bush in 2004. Table 7 shows the results of tests of the relationship between the spatial SDT pattern and election results. As expected, the negative correlation between the SDT factor and the Bush vote weakens as one moves from the 50 
TABLE 7 Zero-order correlation between the SDT factor and the percent voting for Bush in 2004, and partial correlations after controls for structural and cultural variables (all US counties and counties with at least 25,000 inhabitants)

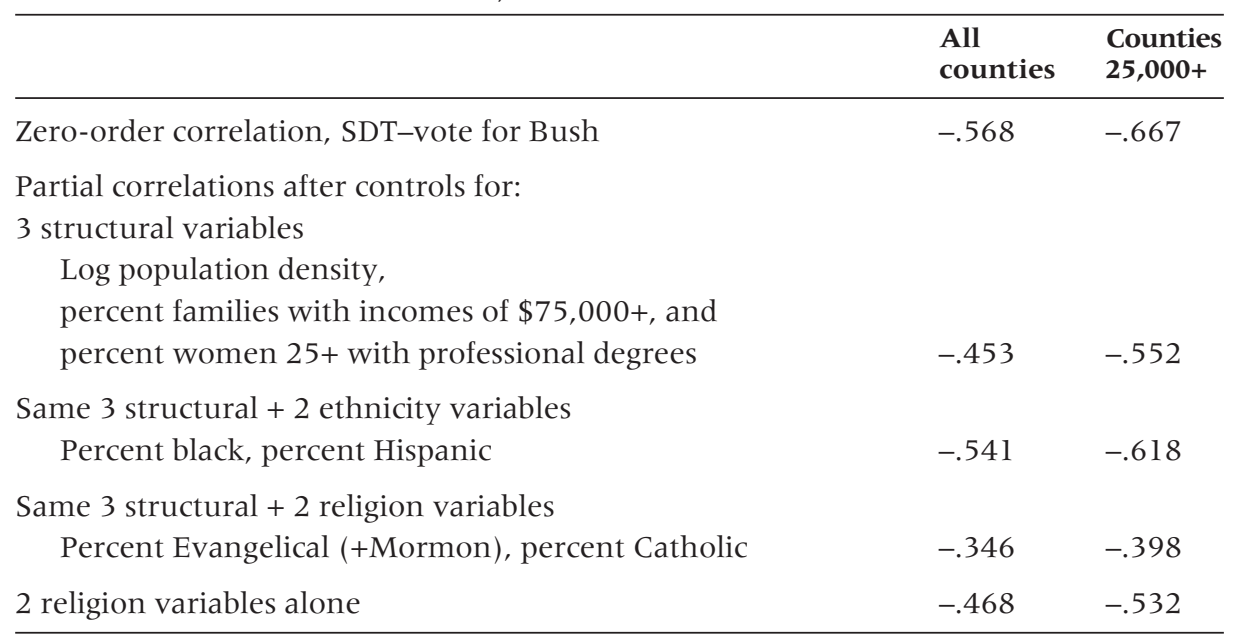

states to the 3,141 counties, from -.88 to -.57 . There are various reasons for this reduction in the strength of association. The classic explanation is that many counties have very small populations so that there is increased volatility in the measurements, particularly the demographic measurements. ${ }^{6}$ When we rerun the analysis for the 1,559 counties with at least 25,000 inhabitants, the zero-order correlation between the SDT factor and the vote for Bush is restored to -.67. This is again indicative of a strong correspondence between a detailed voting map and an SDT map.

What happens if controls are introduced for variables that are commonly considered causal antecedents of both voting patterns and demographic household formation patterns? If the original correlation is reduced to a level close to zero after such controls, there will no longer be a basis for considering any spatial causal relationship (in either direction) between the second demographic transition and voting. If the partial correlation is reduced but still substantially larger than zero, then the control variables are partially but not entirely responsible for the original correlation. In that instance, there is room for a direct causal interpretation between SDT and voting outcomes, but the effect is smaller than would be implied by a full causal interpretation of the zero-order correlation.

As in the analysis by states in Table 5, the best predictor of voting in each set of structural determinants was entered as a control variable in Table 7. For the degree of urbanization this was the logarithm of population density; for wealth the percentage of families with incomes of $\$ 75,000+$; and 
for education the percentage of women aged 25+ with professional degrees. The other structural indicators are strongly correlated with one of these three, and any additional use of multicollinear information is largely redundant and will not improve the results. In addition to the three best structural controls, two variables are introduced to capture ethnic heterogeneity at the county level: the percentage black and the percentage Hispanic in 2000. To capture the religious factor, two variables are added: the percentage Catholic and the percentage Evangelical or Mormon among church adherents (Jones et al. 2002).

The results in Table 7 indicate that the control for five variables (capturing urbanization, wealth, female education, Evangelical/Mormon, and Catholic adherence) is the most powerful in reducing the zero-order correlation between the second demographic transition and the Bush vote. The combination with ethnic composition added to the three structural indicators yields a less marked reduction. But in either column of Table 7, the smallest partial correlation is still far from zero, and the most potent combination of control variables cannot reduce the original correlation by half. These results still mean that we cannot discard the possibility of a direct causal effect of the county demographic pattern on the 2004 presidential election outcome. The objection to this causal inference as it now stands is that there could be some set of control variables not included in this analysis for which the partial correlation will be close to zero. But any such new control variable (or variables) must be correlated strongly with both the voting and the demographic patterns and weakly correlated with the controls already used in Tables 5 and 7. The hunting season is open.

Aside from the effect of volatility of several measures for counties with small populations, there is another reason for the reduction of the SDT-voting correlation when 3,141 counties are considered instead of 50 states. The reason emerges in Table 8 , where the analysis has been run separately for the counties within the four census regions and nine census divisions in the United States. The national correlations, both zero order and partial, are pulled down by weak relations for the South, and particularly for the two South Central divisions. By contrast, the zero-order and partial correlations remain very high for the counties in New England, the Mid-Atlantic states, and the Mountain and Pacific states. Hence, Southern voting patterns may still be conditioned by powerful determinants other than those connected to the unfolding of the second demographic transition, such as the persistence of older ethnically- or social-class-based political affiliations and antagonisms. Recall that the spatial distribution of the SDT factor shows that most of the South is in the very early stages of the second demographic transition. Likewise, spatial distributions of the black and Hispanic populations show them to be concentrated in these census divisions as well. 
TABLE 8 Zero-order and partial correlations between the SDT factor and the vote for Bush according to different aggregations, US counties within census regions and divisions

\begin{tabular}{lccccccc}
\hline & $\begin{array}{l}\text { Number } \\
\text { of } \\
\text { counties }\end{array}$ & $\begin{array}{l}\text { Zero- } \\
\text { order } \\
\text { corre- } \\
\text { lation }\end{array}$ & $\begin{array}{l}\text { 3 struc- } \\
\text { tural } \\
\text { variables }\end{array}$ & $\begin{array}{l}\text { 3 struc- } \\
\text { tural }+ \\
\text { 2 ethnic } \\
\text { variables }\end{array}$ & $\begin{array}{l}\text { 3 struc- } \\
\text { tural + } \\
\text { religious } \\
\text { variables }\end{array}$ & $\begin{array}{l}\text { 2 ethnic } \\
\text { variables }\end{array}$ & $\begin{array}{l}\text { 2 religious } \\
\text { variables }\end{array}$ \\
\hline United States & 3,141 & -.568 & -.453 & -.541 & -.346 & -.600 & -.468 \\
Region & & & & & & & \\
Northeast & 217 & -.803 & -.729 & -.725 & -.635 & -.739 & -.684 \\
Midwest & 1,055 & -.605 & -.518 & -.506 & -.454 & -.557 & -.570 \\
South & 1,424 & -.415 & -.365 & -.380 & -.243 & -.364 & -.288 \\
West & 445 & -.773 & -.639 & -.646 & -.513 & -.760 & -.681 \\
Division & & & & & & & \\
New England & 67 & -.700 & -.482 & -.461 & -.414 & -.629 & -.665 \\
Mid-Atlantic & 150 & -.790 & -.552 & -.494 & -.442 & -.601 & -.680 \\
East North Central & 437 & -.606 & -.616 & -.608 & -.525 & -.537 & -.523 \\
West North Central & 618 & -.572 & -.462 & -.442 & -.395 & -.542 & -.549 \\
South Atlantic & 590 & -.510 & -.406 & -.500 & -.339 & -.569 & -.455 \\
East South Central & 364 & -.252 & -.287 & -.347 & -.247 & -.168 & -.185 \\
West South Central & 470 & -.284 & -.286 & -.234 & -.162 & -.167 & -.147 \\
Mountain & 280 & -.750 & -.592 & -.598 & -.469 & -.740 & -.661 \\
Pacific & 165 & -.733 & -.636 & -.625 & -.582 & -.700 & -.742 \\
\hline
\end{tabular}

NOTES: For definitions of variables see Table 7. The aggregations are US census regions and US census divisions, «http:// www.census.gov/geo/www/us_regdiv.pdf".

SOURCE: Census of Population and Housing, summary files and microdata files; Natality detail file, 1988; and Religious Congregations and Membership in the United States: 2000.

\section{Conclusions}

Allan Carlson's argument, cited at the outset, for US demographic exceptionalism starts from the observation that the overall US total fertility rate is much higher than that of the European Union and Japan, or for that matter the TFR of the rest of the industrialized world. This is clearly true. But he argues that this is not due to the contribution of ethnic minorities, whether black or Hispanic, but to white fertility itself. Carlson locates the explanation in "the higher degree of religious identification and behavior" in the United States than in any other industrialized country.

Is there such an "American exceptionalism"? That the American total fertility rate is close to 2.0 is the result of the following circumstances. Although non-Hispanic white fertility dropped below replacement, it stayed in the vicinity of 1.8, and that was high enough for the contribution of the black and especially of the Hispanic population, which together form about a quarter of the US population, to raise the TFR of the United States as a whole to replacement level. The TFR of the Hispanic population has re- 
mained consistently high at around 2.7 to 2.9 since 1990 . The contribution of black fertility is of less importance since it has been close to replacement level during the last decade. The total fertility rate of Asians, Pacific Islanders, and American Indians has been almost identical with that of non-Hispanic whites (Sutton and Mathews 2004: 31). Hence, the ethnic factor is important in maintaining the overall American TFR around replacement level. In effect, a large segment of the Hispanic population is still completing its first demographic transition. The conclusion here is that the United States is a textbook example of the second demographic transition where immigration and higher immigrant fertility compensate for subreplacement fertility of much of the native population.

Is there "American exceptionalism" among the non-Hispanic white population? If one is judging solely on the basis of the TFR, the answer is no since only four states with small populations have fertility levels above replacement. But if we take a more balanced view based on multiple indicators, the answer is both yes and no.

Yes, there is an "American exceptionalism" among a non-negligible section of the population. That section is mainly located in the Midwest, the Great Plains, and the South. It is on average much more rural than metropolitan, less well educated, adheres more to Evangelical Christianity or Mormonism, and tends to have higher levels of divorce. With respect to teenage fertility and young single mothers, there is a divide between the Northwestern and Southeastern states, with the latter still having high to very high levels of unmarried fertility among young mothers (both whites and blacks). Although the rates are falling, several American states still have teenage fertility levels that are the highest in the industrialized world.

No, there is little or no "American exceptionalism" in the remainder of the United States, mainly along the northern Atlantic, the Pacific, the Great Lakes, and the less religious West (Arizona, New Mexico, Colorado). This is the part of America where such features of the second demographic transition as lower and later fertility and tolerance for cohabitation have been emerging in much the same way as in western Europe and Canada (see Juby and Le Bourdais 2005 for recent Canadian figures, and Bernier and Roy 2006 for a detailed analysis of Canadian patterns). This is the America with higher education and higher incomes, greater concentration in metropolitan areas, and high abortion figures but also lower teenage fertility and lower divorce.

Hence the picture would be better described by the term "American bipolarity" than "American exceptionalism." Furthermore, the strong correlation between this demographic duality and the country's current political divide is more typical of textbook transitions than of an exceptional case. As indicated before, the French, Swiss, Belgian, German, Portuguese, and Italian historical first demographic transitions all exhibited clear con- 
nections with the political maps (e.g., Livi Bacci 1977; Lesthaeghe and Wilson 1986), and this has continued to be the case for the regional patterns of the second demographic transition as well (Lesthaeghe and Neels 2002). Seen from this international perspective, the patterning of the second demographic transition in the United States is not exceptional at all. Moreover, the two SDT sub-dimensions of "postponement" and "cohabitation" are more strongly correlated in the United States both in time and space than in the EU-25, and from that perspective the American SDT is also a textbook example.

The resistance of the spatial correlation between the 2000 and 2004 presidential election results and the SDT factor to controls warrants further attention. It appears that this relationship cannot be totally explained by the effects of such common structural causal antecedents as urbanization, personal and household wealth, or education. Also the addition of a religious trichotomy (Catholic, Evangelical/Mormon, other) or an ethnic one (black, Hispanic, other) is largely inadequate to account for the correlation between voting results and the SDT factor. As already noted, this is not proof of direct causality from SDT to election outcomes, since theoretically there is always a possibility of finding better-performing control variables. But unless such better controls are identified and tested, the hypothesis that the US spatial SDT pattern influenced the last two presidential elections cannot be refuted. The only qualification to this statement that we can make so far is that this is not a strong pattern in the South Central counties, where voting outcomes may still be determined by older ethnic or social contrasts.

These results also shed additional light on the "culture war" debate. The reference to the nineteenth-century Kulturkampf in Germany is probably an appropriate one, but the translation of Kampf (strife, struggle) as "war" is definitely an exaggeration. But then, J. D. Hunter (1991), the author of Culture Wars: The Struggle to Define America, does not argue that the US population is polarizing. He documents that political and community elites have produced antagonistic discourses since the 1980s. But on the other hand, the denial of the existence of any cultural polarization among the public at large seems an exaggeration as well. Fiorina, Abrams, and Pope (2005) refute the "myth of a polarized America" on the grounds that shifting positions of political parties and their candidates can produce effects that are identical with those of shifting public positions. Hence, their diagnosis is indeed "centrist voters and polarizing elites" (pp. 167-180).

Our findings are not in agreement with Fiorina et al.'s thesis of an unchanging public. Recall that both the SDT factor as measured here and its strong link to voting patterns are based on actual behavior of the entire American population. What we find suggests that not just the rhetoric of media, politicians, and community leaders on abortion, same-sex marriage, and other issues, but also the regional population variations in demographic 
behavior have been contributing to the polarization witnessed in the last two presidential elections. The middle group or "centrist voters" can still be the modal one, but the more extreme ends of the spectrum have moved farther apart. We have shown that such a change in population distributions is not solely the product of media or elite discourse but also the likely product of shifting demographic behavior, known as the second demographic transition. What makes the United States particularly interesting in the overall Western context is that the conservative and religious right is openly and vocally trying to fight back (e.g., with amendments seeking to ban samesex marriage, closure of abortion clinics). This has not happened in Europe, Canada, or Australia. But despite a number of American idiosyncracies, the bottom line is that the current US family and household patterns follow all major "second demographic transition" trends, and that the spatial contrasts in this respect have proved to be quite capable of co-determining important political outcomes.

\section{Notes}

1 The only areas where cohabitation and out-of-wedlock fertility have remained very modest in Europe are Poland, Ukraine, Greece, and Cyprus.

2 By 2004, the United States had 3,142 counties. However, the newest county (Broomfield county, Colorado) was formed after the 2000 census. Since all indicators except for the 2004 presidential election results are based on 2000 or earlier years, Broomfield county is excluded from the analysis.

3 We treat Washington, DC as a county.

4 Owing to confidentiality concerns, 1988 was the last year that NCHS produced detailed natality files that had county-level information for all counties. In subsequent years, only counties of 100,000 or more can be identified.
5 Especially in the Mediterranean countries, postponement of marriage and parenthood preceded the emergence of cohabitation by at least two decades.

6 The measurements for most counties with a population of less than 5,000 have been combined with contiguous counties (based on Census Bureau definitions of Public Use Microdata areas) to produce a weighted measurement that is assigned to all small counties in the same PUMA. While this provides more stability in the measurement, it introduces a different sort of error. Not all PUMAs are homogeneous. Thus, in some cases we have combined apples and oranges. When the analysis is restricted to counties with a population of 25,000 or more, we not only eliminate small sample sizes, we also eliminate the error based on combining several small units.

\section{References}

Ariès, P. 1980. "Two successive motivations for declining birth rates in the West," Population and Development Review 6(4): 645-650.

Bernier, J. and L. Roy. 2006. La politique familiale, les tendances sociales et la fécondité au Québec: une expérience quasi nordique? Rapport, Québec: Ministère de la Famille, des Aînés et de la Condition feminine, March.

Carlson, A. C. 2005. "The fertility gap: Recrafting American population," Family Policy Lectures, Family Research Council, 14 December: 1-14 "www.frc.org/get.cfm?i=PL03G01\&v= PRINT». 
Coleman, D. 2003. "Why we don't have to believe without doubting in the second demographic transition: Some agnostic comments," Conference of the European Association for Population Studies (EAPS), Warsaw. Unpublished Powerpoint slides.

Council of Europe. 2005. Recent Demographic Developments in Europe-2004. Strasbourg: Council of Europe Publishing. CD-ROM with detailed country data.

Eberstadt, N. 2004. "Population power: Another Transatlantic divergence," AEI on line, American Enterprise Institute, 12 November.

Fiorina, M. P., S. J. Abrams, and J. C. Pope. 2005. Culture War? The Myth of a Polarized America. New York: Longman and Pearson Education.

Gallagher, M. 2006. "Europe's marriage crisis and ours," Illinois Family Institute, 3 March "Www.illinoisfamily.org/informed/contentview.asp?c=32161.

Hunter, J. D. 1991. Culture Wars: The Struggle to Define America. New York: Basic Books.

Inglehart, R. 1970: The Silent Revolution. Princeton, NJ: Princeton University Press. . 1990: Culture Shift in Advanced Industrial Society. Princeton, NJ: Princeton University Press.

Jones, D. et al. 2002. Religious Congregations and Membership in the United States 2000: An Enumeration by Region, State and County Based on Data Reported for 149 Religious Bodies. Nashville, TN: Glenmary Research Center. Web site: «http://www.thearda.com».

Jones, G. W. 2006. "Delayed marriage in Pacific Asia, gender relations and the fertility crisis," Asia Research Institute Working Papers series no. 61. Singapore: National University of Singapore.

Juby, H. and C. Le Bourdais. 2005. “Families in transformation: Implications for family research and policy," unpublished paper for Social Development Canada, Knowledge and Research Directorate, November.

Lesthaeghe, R. and K. Neels. 2002. "From the first to a second demographic transition: An interpretation of the spatial continuity of demographic innovation in France, Belgium and Switzerland," European Journal of Population 18: 325-360.

Lesthaeghe, R. and J. Surkyn. 2006. "When history moves on: Foundations and diffusion of a second demographic transition," in R. Jayakody, A. Thornton, and W. Axinn (eds.), International Family Change: Ideational Perspectives. Mahwah, NJ: Lawrence Erlbaum and Associates. Forthcoming.

Lesthaeghe, R. and D. J. van de Kaa. 1986. "Twee demografische transities?," in R. Lesthaeghe and D. J. van de Kaa (eds.), Groei of Krimp. Annual book issue of "Mens en Maatschappij," Deventer (Netherlands): Van Loghum-Slaterus, pp. 9-24.

Lesthaeghe, R. and C. Wilson. 1986. "Modes of production, secularization and the pace of the fertility decline in Western Europe, 1870-1930," in A. J. Coale and S. C. Watkins (eds.), The Decline of Fertility in Europe. Princeton, NJ: Princeton University Press.

Livi Bacci, M. 1977. A History of Italian Fertility During the Last Two Centuries. Princeton, NJ: Princeton University Press.

Longman, P. 2004. "The global baby bust," Foreign Affairs (May/June): 64-79.

- 2006. "The liberal baby bust," USA Today, 13 March "Www.usatoday.com/news/opinion/editorials/2006-03-13-babybust_x.htm».

Maslow, A. 1954. Motivation and Personality. New York: Harper and Row.

National Center for Health Statistics (NCHS). 2005. Preliminary Births for 2004. Web site: http:// www.cdc.gov/nchs/products/pubs/pubd/hestats/prelim_births/prelim_births04.htm.

Raley, R. K. 2000. "Recent trends and differentials in marriage and cohabitation: The United States," in L. J. Waite and C. Bachrach (eds.), The Ties That Bind: Perspectives on Marriage and Cohabitation. New York: Aldine de Gruyter, pp. 19-39.

. 2001. "Increasing fertility in cohabiting unions: Evidence for the second demographic transition in the United States?," Demography 38(1): 59-66.

Raymo, J. and M. Iwasawa. 2006. "Unmarried cohabitation and family formation in Japan," paper presented at the Annual Meeting of the Population Association of America, Los Angeles, 30 March-1 April.

Retherford R. D. and N. Ogawa. 2005. “Japan's baby bust: Causes, implications and policy responses," Hawaii: East-West Center Working Papers series - Population and Health Series, no. 118 . 
Seltzer, J. A. 2000. "Families formed outside of marriage," Journal of Marriage and the Family 62: $1247-1268$.

Sutton, P. and T. J. Mathews. 2004. "Trends in characteristics of births by state: United States, 1990, 1995, and 2000-2002," National Vital Statistics Report 52(9). National Vital Statistics System and Centers for Disease Control and Prevention, US Department of Health and Human Services.

Torrey, B. and N. Eberstadt. 2005. "The North America fertility divide—Canada's baby bust," Policy Review 132: 39-56.

US Census Bureau. 2003a. Census of Population and Housing 2000: Public Use Microdata Sample (PUMS); 5 Percent Sample. . 2003b. Census of Population and Housing 2000: Summary Files.

Ventura, S. and C. Bachrach. 2000. "Nonmarital childbearing in the United States, 1940-99," National Vital Statistics Report, 48(16) (revised), National Center for Health Statistics and Centers for Disease Control and Prevention, US Department of Health and Human Services.

van de Kaa, D. J. 1987. “Europe's second demographic transition," Population Bulletin 42(1). 2002. "The idea of a second demographic transition in industrialized countries," Sixth Welfare Policy Seminar. Tokyo: National Institute of Population and Social security, 29 January. 